pag

Business School

WORKING PAPER SERIES

\begin{tabular}{c|l} 
Working Paper & $\begin{array}{l}\text { e-Business Models for Financial } \\
\text { Services and Internet Banks }\end{array}$ \\
$2014-217$ & JM. Sahut
\end{tabular}

http://www.ipag.fr/fr/accueil/la-recherche/publications-WP.html

IPAG Business School

184, Boulevard Saint-Germain

75006 Paris

France

IPAG working papers are circulated for discussion and comments only. They have not been peer-reviewed and may not be reproduced without permission of the authors. 


\title{
e-Business Models for Financial Services and Internet Banks
}

\author{
JM. Sahut \\ IPAG Business School, Paris, France
}

\begin{abstract}
Internet is not simply one more distribution channel among the multi-channel strategies used by the financial industry; it is fostering new "e-Business Models" such as Internet-primary banks. However, in spite of its strong development potential, this type of bank has often achieved a weak breakthrough onto this market and shows modest financial results. The goal of this article is to study the "e-Business Model" of Internet-primary banks and to determine if it can perform better than the "Business Model" of a traditional bank.
\end{abstract}

\section{INTRODUCTION}

Internet has given a new dimension to the convergence and the deconstruction of the value chain in the financial sector. Convergence has taken place on three levels:

- convergence of offers; by widening their product range, banks and insurance companies have entered into direct competition,

- convergence of the sub-sectors of the financial industry; banking, insurance and asset management activities increasingly overlap,

- financial institutions and non-finance actors have become more closely linked.

Previously, deconstruction came mainly from the offer side, i.e. from the emergence of new entrants (e.g. consumer credit). With Internet, it comes from the demand side: customers can choose the best supplier depending on their preferences (e.g. real estate loans, online brokering). With the appearance of banks which mainly sell their services by Internet (Internet-primary banks), the major competitive advantage of traditional banks - a network of local branches - has been diminished for certain types of customer. These customers have been attracted by the prospect of accessing their accounts and carrying out bank transactions 24 hours a day, seven days a week without having to go anywhere, and sometimes with a better quality of service than was offered by a bank branch. Moreover, the vast majority of Internet-primary banks charge lower account administration fees than those charged by traditional banks. This has often been used as an argument to attract customers in a nearly saturated market.

The goal of this article is to study the "Electronic Business Model" of Internet-primary banks and to determine if it can outperform the "Business Model" of a traditional bank. After having defined the Business Model and e-Business Model (e-BM) concepts, we will analyze the e-BM of online banks as an economic model through the study of its revenue sources, costs incurred, and how it creates value for customers. Then, we will question its strategic development prospects. Lastly, we look at Internet's impact on performance in the case of both traditional institutions as well as Internet-primary banks.

\section{BUSINESS MODELS IN THE FINANCIAL SECTOR}

\subsection{Business Models and Electronic Business Models}

Many papers have already been written which attempt to clarify this concept due to its dynamic dimension (George \& Bock, 2011). We will look at how this concept has been applied to electronic services: the "Electronic Business Model" (e-BM).

One of the first workable definitions of this concept was provided by Timmers (1998). He defines a BM as being:

- the architecture for product, services and information flows including a description of the model's various business actors and their roles;

- a description of the potential benefits for each business actor involved;

- a description of the sources of revenue.

Other researchers have since expanded this idea. Linder \& Cantrell (2000) state: "It's a rich, tacit un- 
derstanding about how all the pieces work together to make money". These authors confirm this vision of BMs by the fact that $62 \%$ of the company directors they interviewed found it difficult to describe their BM over and above its success. While for Loilier \& Tellier (2001), a BM can be likened to a firm's value creation method.

In fact, defining what a BM is can be a difficult exercise because this concept is associated with dynamic dimensions such as value creation, competitiveness and organizational change. Porter (2001) in particular described this concept as "fuzzy", "superficial", and "theoretically difficult to grasp". Magretta (2002) specifies that the usual error with respect to BMs is to regard them as being a strategy: "Business modeling is the managerial equivalent of scientific method - you start with a hypothesis, which you can test in action and revise when necessary". For this author, the BM describes in system form, how the firm manufactures and sells a service or a product. Equally, for Afuah \& Tucci (2003), the BM is a basket of activities which allows a business to earn money in a sustainable way. Along the same lines, Demil et al. (2004) approach it as an intermediate concept used to make strategies operational. They define the BM as all the choices which a firm makes in order to generate revenue. Whatever definition you choose, it is important to dissociate the concept of BM from that of strategy and to regard it as a dynamic concept which is constantly reconsidered according to market conditions, technology, regulations, inter-company relations, etc.

The development of ICTs, and specifically the Internet, has generated new activities resulting either from technological innovation (for example Internet portals), from the destruction of value chains (e.g. loan comparison sites), or from new channels (e.g. online brokers). These activities then brought about the appearance of new BMs or redefined those which already existed (Applegate, 2001). For example, Internet strengthens the Research and Development function (a support service according to Porter's value chain concept) by helping in the collective design of products between sites and participants in the value system, by listing the concepts accessible to all the branches of the business and by giving access in real-time to all the sales and services databases. Also, Internet makes it possible to reduce order transmission times by automating both customer and supplier contacts and enables a truly integrated management system to be put in place. The impact of such practices on work efficiency creates an additional added value for the firm (Porter, 2001).

The term "Electronic Business Model" (e-BM) has since appeared to qualify the BM of these new activities. As the concept is derived from that of BMs, it is also difficult to define and can be understood in different ways (Casadesus-Masanell \& Ricart,
2010). This is why many authors have tried to define it using a heuristic approach, in other words starting from their observations of the market. The result has been a wide diversity of studies which cover both the number of e-BMs identified and their characteristics: Timmers (1998) counted eleven different types, Loilier \& Tellier (2001) counted five and Rappa (2004) nine.

Even if many similarities are identified, convergence between these typologies started to take place in 2001 with the analysis of value creation. Indeed, Timmers (1998) has a vision which focuses on the internal dynamics of e-BMs and on their interaction with the environment. As for Mahadevan (2000), he prefers a "macro" vision in which e-BMs depend on the types of relations which exist between actors from the same market. Applegate's article (2001) marks a transition by putting forward a very precise classification of e-BMs concerning value creation for the e-BM (sources of differentiation, revenue and costs incurred), but the value created for customers is not a central issue. It wasn't until Novak \& Hoffman's article (2001) that the different dimensions of e-BMs were brought closer together. They present "Customer Model Integration" in which the definition of an e-BM is jointly linked to both value models for customers and revenue models.

Figure (1): Values, Revenues and Customer Model Integration Source: Adapted from Novak and Hoffman (2001)

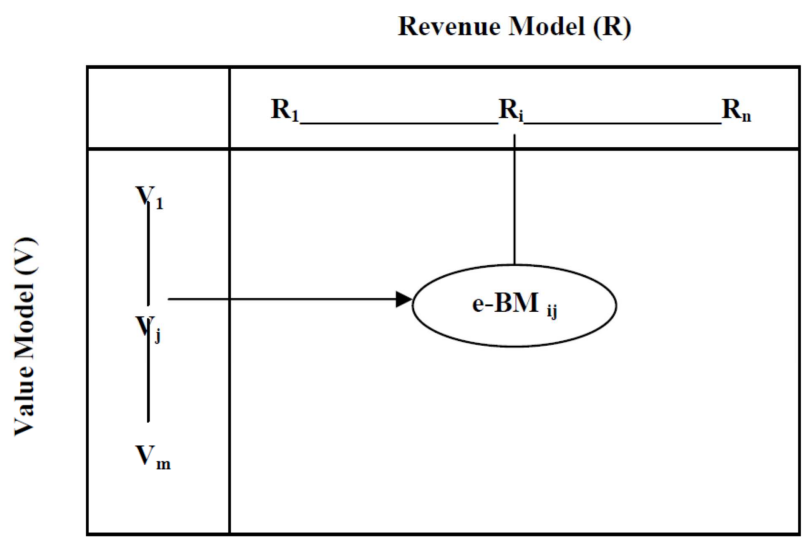

In particular, Novak and Hoffman identify twelve value models. However, their revenue or value models created for customers cannot be regarded as exhaustive for two primary reasons:

- Given the difficulty of defining only one typology of e-BM, it is possible to present as many models as there are combinations of sources of revenue; the appearance of a new e-BM means the existence of new original combination of sources of revenue, even the creation of a new element for generating revenue;

- It would seem that revenue sources other than those presented by Novak and Hoffman can exist, for example the sale of customer data (e-mail, addresses, purchasing behavior...), a purchase made in 
a store following the consultation of the product on Internet, etc.

Moreover, the type of activity strongly influences the structure of an industry (Casadesus-Masanell \& Ricart, 2010). As a result e-BMs are very different from one sector to another. Hereafter, we will look at the financial sector and at the different e-BMs which characterize it, and more specifically, at Internet banks.

\subsection{Typology of e-Business Models for financial services}

Due to their apparent contradictions, it is difficult to come to any firm conclusions on the positioning of Internet-primary Banks compared to more general eBMs. On the other hand, if one focuses on the specific sector of financial services, a greater convergence of e-BMs can be clarified by studying the work of Horsti et al. (2005), Zott \& Amit (2010), and George \& Bock (2011).

Table (1): Typology of e-BMs for financial services

\begin{tabular}{|c|c|c|c|}
\hline Type & Characteristics & $\begin{array}{c}\text { Revenue } \\
\text { Created }\end{array}$ & Value Model \\
\hline $\begin{array}{l}\text { Vertical Por- } \\
\text { tal } \\
\text { Financial } \\
\text { Portal [MUY } \\
01] \\
\text { Portals [SAH } \\
01]\end{array}$ & $\begin{array}{l}\text { They mainly offer } \\
\text { general or special- } \\
\text { ized information ser- } \\
\text { vices in several } \\
\text { fields. Some have } \\
\text { created "personal fi- } \\
\text { nance spaces", like } \\
\text { Yahoo with "Yahoo } \\
\text { Finance", which pro- } \\
\text { poses, in addition to } \\
\text { informational ser- } \\
\text { vices, transaction } \\
\text { services (credit card, } \\
\text { account aggregation, } \\
\text { advice about stock } \\
\text { market investments, } \\
\text { etc). }\end{array}$ & $\begin{array}{l}\text { Advertising, } \\
\text { Affiliation, } \\
\text { Commission, } \\
\text { Sale of prod- } \\
\text { ucts and ser- } \\
\text { vices. }\end{array}$ & $\begin{array}{l}\text { Brokerage; } \\
\text { Content; } \\
\text { Search; } \\
\text { Communi- } \\
\text {-cation; } \\
\text { Community; } \\
\text { Affiliate, } \\
\text { Transaction. }\end{array}$ \\
\hline $\begin{array}{l}\text { Aggregator } \\
\text { [MUY 01] } \\
\text { Aggregators } \\
\text {-Brokers } \\
\text {-Quoters } \\
\text { [SAH 01] }\end{array}$ & $\begin{array}{l}\text { These are sites } \\
\text { whose role is to act } \\
\text { as online intermedi- } \\
\text { ary between different } \\
\text { actors. "Quoters", } \\
\text { contrary to brokers, } \\
\text { do not carry out the } \\
\text { transaction, they are } \\
\text { infomediaries which } \\
\text { bring business to vir- } \\
\text { tual agencies, or } \\
\text { compare offers for } \\
\text { consumers. }\end{array}$ & $\begin{array}{l}\text { Brokers: } \\
\text { Sale of prod- } \\
\text { ucts and ser- } \\
\text { vices. } \\
\text { Quoters: } \\
\text { Commission, } \\
\text { Advertising, } \\
\text { Affiliation. }\end{array}$ & $\begin{array}{l}\text { Brokers: } \\
\text { Content, } \\
\text { Transaction. } \\
\text { Quoters: } \\
\text { Content, } \\
\text { Brokerage. }\end{array}$ \\
\hline Speciality & These are producers & Commission, & Out- \\
\hline
\end{tabular}

\begin{tabular}{|c|c|c|c|}
\hline $\begin{array}{l}\text { manufactur- } \\
\text { er } \\
\text { [MUY 01] }\end{array}$ & $\begin{array}{l}\text { of financial services } \\
\text { (like Visa, equity } \\
\text { funds, traditional } \\
\text { banks, etc) which } \\
\text { distribute them } \\
\text { through their own } \\
\text { network, or external } \\
\text { networks (resale or } \\
\text { co-branding). }\end{array}$ & $\begin{array}{l}\text { Sale of prod- } \\
\text { ucts and ser- } \\
\text { vices. }\end{array}$ & $\begin{array}{l}\text { sourcing, } \\
\text { Transac- } \\
\text { tion. }\end{array}$ \\
\hline $\begin{array}{l}\text { Virtual } \\
\text { agencies } \\
\text { (banks, in- } \\
\text { surance, or } \\
\text { broking on } \\
\text { line) [SAH } \\
01]\end{array}$ & $\begin{array}{l}\text { These are online } \\
\text { banking, investment } \\
\text { or insurance services. } \\
\text { The sites with the } \\
\text { best performance of- } \\
\text { fer, in addition to ad- } \\
\text { vanced information } \\
\text { and transaction ser- } \\
\text { vices, customer rela- } \\
\text { tions management } \\
\text { services (tools to } \\
\text { help in decision- } \\
\text { making, online ad- } \\
\text { vice, development of } \\
\text { personalized prod- } \\
\text { ucts, etc). } \\
\text { The main difference } \\
\text { with bro- } \\
\text { kers/aggregators is } \\
\text { that they are not sat- } \\
\text { isfied to aggregate } \\
\text { the existing offer. } \\
\text { They mainly sell } \\
\text { products of their } \\
\text { brand. }\end{array}$ & $\begin{array}{l}\text { Product sales } \\
\text { and services, } \\
\text { Commission, } \\
\text { Advertising. }\end{array}$ & $\begin{array}{l}\text { Out- } \\
\text { sourcing, } \\
\text { Transac- } \\
\text { tion, } \\
\text { Content, } \\
\text { Broker- } \\
\text { age, } \\
\text { Commu- } \\
\text { nity. }\end{array}$ \\
\hline
\end{tabular}

Between these different e-BMs for financial services, there exist several forms of exchange, partnership and strategic alliances. In particular, portals offer virtual banking agencies, aggregators and financial actors in general a space to advertise and be referenced. Moreover, certain portals develop cobranding strategies (coproduction) by coming together with certain producers to produce or sell joint services. Thus while calling into question the comparative advantages of traditional actors, the financial service sector on Internet has become very competitive and obliges actors to innovate by creating alliances, partnerships or mergers making it possible to build up new comparative advantages, to catch up with competitors, or to break into new markets. The movement which recently saw a consolidation of online brokers in Europe illustrates this phenomenon. Between 2002 and 2006, 22 brokers were taken over or merged in France (Les Echos, $n^{\circ} 19783$, 30/10/2006).

Moreover, it is difficult to understand the financial equilibrium of e-BMs because not only have they brought about new commercial concepts but, above 
all they have provided a new logic for value creation. In the start-up phase, companies in the ebusiness field generate large negative free cash flows for a certain length of time, before turning round and progressing exponentially. This type of cycle which is more marked than for traditional industries can be explained in particular through the theory of the network economy (Shapiro and Varian, 2003). In fact, the main specificities of e-BMs which develop in an economy based on networks show that:

- profitability is only achieved by developing the use of a good or product (one speaks about "an experience good") because the consumers are not motivated to buy or carry out transactions on line when they have doubts about the quality of the products or the operation's level of security. Once the "reputation" of the e-BM has been made, this type of psychological barrier decreases;

- profitability is determined by "the attention" paid to the e-BM. In fact, Internet provides an important mass of information with rapid, permanent and inexpensive access. Many BMs therefore try to benefit from this by setting up an informational website. Thus, gradually, competition in the physical markets has moved onto Internet. However, there are so many websites for companies selling the same products that saturation has been reached: far from increasing their visibility, these companies have provoked an "attention shortage". It is therefore imperative for an online bank wishing to "grab the attention" of customers from other banks already offering Internet Banking services, to propose superior value to that offered by its competitors. This requires big investment (in the development of services and the acquisition of customers) and explains the high level of negative free cash flows suffered by e-BMs at the beginning of their life cycle;

- profitability depends on the technological infrastructure and the capacity to give added value to the offer on Internet. In fact, contrary to a BM, e-BMs are characterized by the high costs of technological infrastructure (computers, software, data-base servers, computer maintenance, network equipment, etc.). This technological infrastructure can be the basis for the acquisition of a competitive advantage as soon as it improves capacity for storing, researching, sorting, filtering and sending out information (Applegate, 2001). It increases, at the same time, the value of the information itself (and the service provided to the customers in general). But the high fixed cost that technology represents cannot be amortized until a critical number of customers has been reached. However, such an acquisition takes a long time to achieve.

Lastly, we can notice that the profits expected by Internet Banking services are more indirect, in other words they come from efficiency to the detriment of productivity in value. Even before the appearance of
Internet banks, Rowe (1994) had noticed that the IT expenditure of French banks was increasing faster than productivity. He saw this phenomenon as confirmation of "the Solow paradox".

Should we therefore call into question Internet's productivity and its contribution as a channel of distribution? Will the traditional banks continue to perform the same with or without Internet? What are an online bank's real prospects for profitability?

\section{E-BUSINESS MODEL, INTERNET BANKS AND PERFORMANCE}

After having analyzed different e-BMs, their sources of revenue, their costs and their method of creating value, we study the profitability of Internet banking services.

The few studies which have looked into this aspect are divided into two categories: those interested in the introduction of Internet banking services on the profitability of traditional banks (known as clickand-mortar), those comparing the performance of Internet banks with other banks.

The first studies tried to show whether or not the introduction of Internet banking services in traditional banks in the USA increased their profitability (Egland et al, 1998; Carlson et al, 2000; Furst et al, 2002). But, these services represented too small a proportion of the activity to really influence the profitability of these banks. Similarly, Sullivan (2000) showed that the multichannel banks of the 10th Federal Reserve District do not appear more profitable on average when they have a transactional website. In Italy, Hasan et al. (2005) demonstrate a positive relationship, over the 1993-2001 period, between Internet adoption and the profitability of click-and-mortar banks.

More recently, Degado et al. (2007) studied the impact of the adoption of Internet Banking services on the performance of 72 commercial banks in Spain over the period 1994-2002. They conclude that the effects of this adoption take time to appear and result in a fall of overhead expenses. One need 1.5 year to notice a significant increase in ROA (return on assets) and three years for ROE (return on equity). In this context, Internet is used more as a complementary channel than as a substitute to the physical branches.

These contrasting conclusions are debatable because they are based on average results obtained at the beginning of the development of these services. Thus they depended more on the customers' adoption of Internet than on the real contribution of Internet Banking services on the overall profitability of the bank. In fact, these studies have mainly highlighted the problems of measuring the profitability of these services. 
The second wave of studies tried to free themselves from these limits by defining a broader measurement of the performance of Internet banks compared to that of the other banks. We are going to concern ourselves mainly with this second type of study. But beforehand, we will look at performance measurement in the banking sector.

\subsection{How to measure profitability?}

Demirguc-Kunt \& Huizinga (2000) highlight that the approach to profitability in banking and finance is characterized by its complexity and its multiform aspect. They explain their analysis through five main points:

- The merging of "raw material", "money deposited", "final product" and "money loaned" : the fungibility of money makes it more complicated to calculate profitability due to the difficulty of dissociating resources from their uses;

- The impossibility of establishing provisions of profitability in the short term because of the existence of several uncertainties which are part of bankcustomer relations (loan prepayment, litigation, change of address, etc.);

- The difficulty in establishing profitability per product because traditional banking is based on linked product sales which have high indirect costs;

- The strong regulation (or commoditization) of some products: an innovation in the banking sector cannot be patented and can easily be copied;

- The strong constraint of rigidity of costs in banking which are mainly "overhead costs" and indirect. Defining the profitability of a product, a customer segment or a center of responsibility (branch, area, etc.) is a complicated task and depends on method of indirect cost allocation.

For all these reasons, banks performances are assessed ex-post starting from general accounting indicators such as the level of deposits, the losses on loans, the ROA (return on assets) or the ROE (return on equity). But, in the case of a comparison of the performance of newly created Internet banks with that of traditional banks, these indicators (ROA and ROE) are not very relevant because the net income can be negative (because the activity is starting up), and they do not take into account other elements such as "possible market power" (Shepherd et al., 1999).

Among the other methods used, the most famous is the profit efficiency model (DeYoung, 2005). This method allows us to identify between the technology-based scale effects and the technology-based experience effects, showing whether the profitability gaps evaporate as Internet banks grow larger, gain experience and capture economies of scale.

For Cyree et al. (2008):"Profit efficiency indicates how well management produces outputs for a given input mix along with other market characteristics and is measured as the distance from the bestpractice frontier". Moreover, this methodology captures "technology-based experience" and "technology-based scale" effects.

\subsection{Do Internet Banks give a superior performance?}

On the basis of the idea that "experience" could be a determinant of cost reduction and production efficiency, DeYoung (2001) presented a first comparison of the ROA between newly chartered banks (newly created traditional banks) and Internet banks (Internet-primary banks) between 1997 and 1999. He notes that the Internet-primary banks show significantly lower profits than those achieved by the newly chartered banks because of difficulties generating deposit accounts and higher non-interest expenses. The gap is very wide during the first two years but is reduced quickly thanks to technology experience effects. The growth rate of the Internetprimary banks declines to meet that of the newly chartered banks. The banks then progress at the same rate except for the deposit-to-asset ratio. The maturity effects are similar for the two types of bank. Lastly, Internet-primary banks, just like the newly chartered banks, can only reach the same profitability (ROA) as traditional banks at the end of approximately 10 years of activity (DeYoung, 2001).

In a second study, DeYoung (2005) confirms these results by using the profit efficiency model. He shows that the Internet-primary bank startups tended to underperform the branch bank startups over the period 1997-2001 in the USA. This seems to call into question the viability of the Internet bank e-BM. One can conclude from this that the success of an Internet bank is only possible if it reaches a sufficient level of economy of scale and has efficient management practices, particularly for cost management. The more recent results from Cyree et al. (2008), which study the performance of Internet-primary banks and newly chartered traditional banks from 1996 to 2003, provide more details of these performance gaps with certain conflicting conclusions to the studies of DeYoung $(2001,2005)$. Their univariate analysis shows that Internet-primary banks have lower ROA, ROE, loan losses, and net-interest margin, compared to newly chartered traditional banks. But, they indicate that the Internet-primary banks are more profit efficient than the newly chartered traditional banks. In fact, several elements can justify the performance gap of Internet banks with traditional banks especially when starting up (EFMA, 2013):

- Incompressible structural costs: These are expenses inherent to all banking activities and are mainly composed of high fixed charges and costs of IT development. In the case of Axa Banque, these IT costs account for $30 \%$ of total operating costs, 
- A high turnover of advisers and the difficulty of arranging schedules for hot line,

- A very high cost of customer acquisition: For Axa Banque, this cost must not exceed 300 euros per customer recruited to be profitable. This stumbling block can only be overcome with a diversification of customer recruitment methods, loss leaders, and precise customer targeting.

On the other hand, other factors are favorable to the development of online services including:

- the specific characteristics of customers who use on line banks: $37 \%$ are on average expert users in Europe. This clientele is autonomous in decision making, they are mainly men, managers, with a high income who subscribe regularly to financial products on line;

- Internauts are more profitable than non-internaut customers. In the case of Axa Banque, their internaut customers bring in $15 \%$ more revenue than other customers as soon as they join and achieve the target revenue after 18 months instead of 30 months on average;

- the potential of productivity for online banks is higher than that of the traditional bank: in the case of Axa Banque, the productivity by employee is 405 customers (which is a higher performance than the average French bank) with a productivity potential which can reach double that of a traditional bank;

- the structure of the net banking income from an online bank is very different from that of a traditional bank: for example, Axa Banque draws $70 \%$ of its net banking income from payment methods. The remaining 30\% comes from the banking offer (credit, savings and stock exchange transactions) which have strong development potential;

- the backing of a big group means that certain costs can be minimized by benefiting from a phenomenon of material synergy (compensation operations, debit and credit cards, etc.) and intangible synergy (experience, notoriety, etc.). For example, the Midland Bank provided First Direct with a back office of 7 000 ATMs in Great Britain which was the basis of its success. The risk of the cannibalization of channels, competition between the online bank and the mother company (traditional bank) is low because the banks attract a different clientele.

In fact, these studies and research show that the success of an online bank is mainly conditioned by:

- Building a strong competitive advantage which lies in access to customers and a good understanding of their behavior and tastes. Many banks believed that the competitive advantage depended on the technology used; however, technological advances are very quickly copied. This advantage makes it possible to control the cost of acquiring a new clientele. The support of an institution delivering financial services (insurance, supermarkets, banks, etc.), the creation of an attractive loss leader (savings accounts with a high interest rate like ING Direct, etc.) or an innovating service (for example: online brokers at the end of the 90s, etc.) are the main means of building up a competitive advantage;

- The difficulty of maintaining continuous investments without making profits forces certain online financial operators to merge with each other. This was specially the case of certain online brokers who, when they started dealing on the stock exchange, were able to collect large funds. But, as their period of investing at a loss lengthened, they had difficulties accessing other investments. The only way out for those in most difficulty was to merge. One finds several examples in the case of online banks such as the absorption of ZeBank by Egg (which gave it access to the French market), the merger of First-e (Ireland) and Uno-e (Spain), etc;

- A strong brand which inspires trust from potential customers and which also helps reduce the cost of acquiring new customers.

These conditions highlight the difficulty of creating an online bank for actors from outside the banking sector.

\section{CONCLUSION}

In conclusion, we have shown that the dynamic of the financial services sector on Internet is intensifying and that a certain structuring of the sector can be observed. Indeed, the actors are looking for new "revenues-created values" combinations following the example of online brokers, such as Schwab, who have become information providers for the portals, and are trying to reach a critical size via mergers and strategic alliances.

However, the shape of an e-BM specific to online banks hasn't clearly emerged. Despite the strong development potential of online banks, their survival as a specific e-BM can be questioned because of their weak breakthrough onto the international and national markets and their modest financial results. The most successful actors have concentrated on market niches, like ING Direct in Europe.

One can question the capacity of online banks, as eBMs, to remain banks which are virtual, independent and generalist. In this case, it is extremely probable that they will have to develop their own physical sales network (like Schwab) or enter into partnerships with traditional establishments. Otherwise, they are likely to disappear or be absorbed by traditional banks and become gradually integrated into their multi-channel strategy. 


\section{REFERENCES}

Afuah, A., \& Tucci, C. 2003. Internet Business Models and Strategies. New York: McGraw-Hill.

Applegate, L.M. 2000. Emerging e-Business Models: Lessons from the Field. Boston: Harvard Business School Press.

Berger, A.N., Demsetz, R.S., \& Strahan, P.E. 1999. The consolidation of the financial services industry: Causes, consequences, and implications for the future. Journal of Banking \& Finance 23(2-4): 135-194.

Casadesus-Masanell, R., \& Ricart, J.E. 2010. From Strategy to Business models and onto Tactics. Long Range Planning, 43(2-3): 195-215.

Carlson, J., Furst, K., Lang, W., \& Nolle, D. 2000. Internet Banking: Markets Developments and Regulatory Issues. Office of the Comptroller of the Currency, Economic and Policy Analysis. Working Papers 2000-9.

Cyree, K.B., Delcoure, N., \& Dickens, R. 2008. An examination of the performance and prospects for the future of internet-primary banks. Journal of Economics and Finance. June.

Delgado, J., Hernando, I., \& Nieto M.J. 2007. Do European Primarily Internet Banks Show Scale and Experience Efficiencies? European Financial Management 13 (4): 643-671.

Demil, B., Lecoq, X., \& Warnier, V. 2004. Le business model : l'oublié de la stratégie ?. 13th AIMS Conference, Normandie. 2-4 June.

Demirguc-Kunt, A., \& Huizinga, H. 2000. Financial structure and bank profitability. World Bank, Policy Research Working Paper Series 2430.

DeYoung R. 2001. The financial progress of pure-play internet banks. Bank for International Settlements, Monetary and Economic Department. BIS Papers n 7: 80-86.

DeYoung R. 2005. The Performance of Internet-Based Business Models: Evidence from the Banking Industry. Journal of Business 78 (3): 893-947.

Essayan, M., Rutstein, C., \& Wetenhall, P. 2002. Activate and Integrate: Optimizing the Value of Online Banking. Boston Consulting Group.

EFMA (2013), Banking in a digital world: Entering the next level. EFMA Studies. October

Egland, KL, Robertson, D., Furst, K., Nolle D.E., \& Robertson, D. 1998. Banking over the Internet. Office of the Comptroller of the Currency. Currency Quarterly 17: 25-30.

Furst, K, Lang W.W., \& Nolle D.E. 2002. Internet banking. Journal of Financial Services Research 22: 95-117.

George, G., \& Bock, A.J. 2011. The Business model in Practice and its Implications for Entrepreneurship Research. Entrepreneurship Theory and Practice, 35(1): 83-111.
Hasan, I., Zazzara, C., \& Ciciretti, R. 2005. Internet, Innovation and Performance of Banks: Italian Experience. Unpublished manuscript.

Hensman, M., Van den Bosch, F.A., \& Volberda H. 2001. Clicks vs. Bricks in the Emerging Online Financial Services Industry. Long Range Planning Journal 34: 33235 .

Hernando, I., \& Nieto, M J. 2007. Is the Internet delivery channel changing banks' performance? The case of Spanish banks. Journal of Banking \& Finance 31(4): 1083-1099.

Horsti, A.; Tuunainen, V.K.; \& Tolonen, J. 2005. Evaluation of Electronic Business Model Success: Survey among Leading Finnish Companies. Proceedings of the 38th Annual Hawaii International Conference on System Sciences, Volume 7.

Linder, J., \& Cantrell, S. 2000. Changing Business Models: Surveying the Landscape, Accenture Institute for Strategic Change.

Loilier, T., \& Tellier, A. 2001. Nouvelle Economie. Net organisations. Paris : EMS Eds.

Magretta, J. 2002. Why Business Models Matter? Harvard Business Review, May: 90-91.

Mahadevan, B. 2000. Business Models for Internet-based eCommerce: An anatomy. California Management Review, 42(4): 55-69.

Novak, T.P., \& Hoffman, D.L. 2001. Profitability on the Web: Business Models and Revenue Streams. eLab Position Paper. Owen Graduate School of Management. Vanderbilt University. January: 9-18.

Porter, M.E. 2001. Strategy and the Internet. Harvard Business Review, June.

Rappa, M. 2004. The utility business models and the future of computing services. IBM System journal, 43(1):32-42.

Rowe, F. 1994. Des Banques et des Réseaux : Productivité et Avantages Concurrentiels. Economica: 246-247.

Sahut, J.M. 2001. Vers une révolution du secteur bancaire ? La Revue du Financier. ${ }^{\circ} 131:$ 34-38.

Shapiro, C., \& Varian, H.R. 2003. Information rule. Ethics and Information technology. 5(1): 51-73.

Sullivan, RJ 2000. How has the adoption of internet banking affected performance and risk in banks? Federal Reserve Bank of Kansas City. Financial Perspectives. December: 1-16.

Timmers, P. 1998. Business models for electronic markets. Electronic Markets 8(2): 2-8.

Zott, C., \& Amit, R. 2010. Business model Design: An Activity System Perspective. Long Range Planning, 43(2-3): 216-226. 